\title{
EXTRA-CONTRACTUAL LIABILITY IN INFORMAL BANK COMBINATIONS
}

Transfer by one bank of all or the major part of its business to another bank by way of sale or pledge has been a frequent occurrence during the past two decades. To all appearances, this type of conveyance has been the device most frequently employed ${ }^{1}$ for rescuing banks with either state or national ${ }^{2}$ charters from financial collapse. It is often used by state banking officials as an alternative to the winding up and liquidation of closed institutions which have come into their hands. ${ }^{3}$ A judicial receivership of a defunct bank may culminate in the same fashion. ${ }^{4}$ No less frequently the only parties to the transfer are the private institutions involved, ${ }^{5}$ although the assignment may be carried out under the scrutiny and with the advice of the interested banking authorities. ${ }^{6}$ The receiving bank may be either an organization already existent and functioning, as is usually the case, ${ }^{7}$ or one created for the express purpose of relieving the distressed situation by facilitating the introduction of new capital into the enterprise. ${ }^{8}$ In the former event, the transaction simulates a technical merger or consolidation, except that the statutory recuirements for legal combination are not followed, ${ }^{0}$ and participating banks do not lose their separate corporate entities. Where the transferee is newly created, the transaction bears some resemblance to a corporate reorganiza-

1. A second, but comparatively rarely employed technique for rehabilitating a tottering bank, is the infusion of fresh funds from government agencies. The Reconstruction Finance Corporation is authorized to loan to any bank or trust company. 47 STAT. 6 (1932), 15 U. S. C. A. § 605 (Supp. 1938). 1931).

2. See City National Bank of Huron v. Fuller, 52 F. (2d) 870,873 (C. C. A. 8 th,

3. Instances include Mann v. Bank of Greenfield, 323 Mo. 1000, 20 S. W. (2d) 502 (1929); Lawhead v. Adams, 113 W. Va. 604, 169 S. E. 330 (1933).

4. American Bank \& Trust Co. v. Hon, 48 F. (2d) 588 (C. C. A. 7th, 1931) (new bank already in existence); Sudakovich v. Central Bank of Bingham, 62 Utah 24, 218 Pac. 113 (1923) (transferee newly created).

5. Instances include Burkhalter v. Glenville Bank, 184 Ga. 147, 190 S. E. 644 (1937) ; Jackson v. Chapman, 263 S. W. 958 (Tex. Civ. App. 1924).

6. Caldwell State Bank v. First National Bank, 49 Idaho 110, 286 Pac. 360 (1930); Andrew v. Peoples Savings Bank, 216 Iowa 252, 249 N. W. 352 (1933).

7. Examples of such transactions are Farmers \& Merchants State Bank \& Trust Co. v. Cole, 220 S. W. 354 (Tex. Civ. App. 1920) ; Claus v. Farmers \& Stockgrowers State Bank, 51 Wyo. 45, 63 P. (2d) 781 (1936).

8. Neely v. Rawlings, 64 F. (2d) 655 (C. C. A. 5th, 1933) ; First National Bank in Ada v. Jackson, 180 Okla. 77, 70 P. (2d) 88 (1937).

9. Corporations, being creatures of the legislature, are without power to consolidate or merge, unless such authority is conferred by charter or statute. 8 Tuoupson, Cokporatrons (3d ed., 1927) $\$ 6020$. A transaction cannot be a legal consolidation unless statutory requirements are complied with in entirety. Houston v. Drake, 18 F. Supp. 693 (D. Ariz. 1937). See Comment (1935) 45 YALE L. J. 105. 
tion, but only superficially. ${ }^{10}$ In either situation, the actual conduct of the participant banks follows a substantially uniform pattern. The transferor, the "old bank," turns over its assets to the transferee, the "new bank"; the new bank enters the deposits, and other liabilities, of the old bank on its books and honors instruments payable by the old bank. ${ }^{11}$ On the other hand, the documentary contract between the parties may assume a wide variety of forms. The conveyance may be labeled a sale $\mathrm{e}^{12}$ of assets in consideration of the assumption of all ${ }^{13}$ or specified liabilities; $;^{1+4}$ or it may be called a pledge of assets as security for a loan, the proceeds of which the new bank, as agent, is to distribute to the creditors of the old. ${ }^{15}$

In several respects these informal bank combinations, whatever their superficial dress, are differentiated from the analogous transactions of commercial and industrial corporations. First, with but few exceptions, their motivation is a bona fide endeavor to spare creditors of the distressed financial concern the losses and delays surrounding liquidation and reorganization. ${ }^{10}$ Secondly, there is a growing judicial recognition that banks are not purely private commercial enterprises, but quasi-public institutions dealing with individuals unschooled in the intricacies of finance. ${ }^{17} \mathrm{~A}$ sizeable number of courts, for

10. In the procedure here under discussion, it is extremely rare that a diminution of indebtedness is sought, and so the consent of creditors of the transferor is practically never obtained. Knass v. Madison \& Kedzie State Bank, 269 IIl. App. 585 (1933). The transaction is usually not under judicial auspices, and so does not have the character of a judicial sale on execution. Even where the conveyance follows an equity receivership, the elements of upset price, competitive plans and rival committees, common to equity reorganizations, are absent. Cf. Farmers National Bank v. Sansing, 285 S. WV. 862 (Te: Civ. App. 1926) ; American Bank \& Trust Co. v. Hon, is F. (2d) $58 S$ (C. C. A. 7th, 1931).

11. Assets not assigned may be retained by the old bank to meet obligations not assumed. Ezzard v. State National Bank, 57 Okla. 371, 157 Pac. 127 (1916). Or they may be transferred in trust to a third party to indemnify the new bank against loss. Caldwell State Bank v. First National Bank, 49 Idaho 110, 286 Pac. 360 (1930).

12. Drovers \& Mfechanics National Bank v. First National Bank, 260 Fod. 9 (C. C. A. 4th, 1919); Exchange Bank of Novinger v. Turner, 321 110. 1104, 14 S. W. (2d) 425 (1929).

13. American Bank and Trust Co. v. Hon, 48 F. (2d) 588 (C. C. A. 7th, 1931).

14. Continental Illinois National Bank \& Trust Co. v. Peoples Trust \& Savings Bank, 366 I1l. 366, 9 N. E. (2d) 53 (1937) ; Farmers National Bank v. Sansing, 285 S. W. 862 (Tex. Civ. App. 1926).

15. Farmers \& Mierchants State Bank \& Trust Co. v. Cole, 220 S. W. 354 (Tes. Civ. App. 1920); Miobley v. Hagedorn Construction Co., 168 Ga. 385, 147 S. E. 890 (1929).

16. The absorption, it is true, may not be initiated or sponsored by banling authorities, but very often it has been executed under official supervision. See eases cited supra note 6. Official approval, however, is not generally deemed necessary to the validity of the transaction. For examples, see cases cited supra note 5. But in Illinois, it has been made an essential prerequisite by statute. Il.. Axw. Sr.tr. (1934) Ch. 16\%, \$15.

17. See Knass v. Madison \& Kedzie State Bank, 354 Ill. 554, 567, 185 2T. E 835, 842 (1934). For a collection of judicial declarations to the effect that banls are peculiarly subject to the police power as affected by a public interest, see ZoLwasnir, Busiss 
example, have taken the attitude that while insolvent corporations may in general be permitted to grant preferences among their creditors, it is against public or legislative policy to permit banks to discriminate among their obligees or to dispose of their resources without making provision for all obligations. ${ }^{18}$ In the third place, where banks go through informal combination, the consideration supplied by the transferee is invariably, in practical effect, an undertaking to meet the transferor's liabilities. ${ }^{10}$ In the case of commercial corporations, on the contrary, the consideration may be the issuance of securities to the transferring corporation or its stockholders $;^{20}$ or there may be a failure to provide for any consideration whatsoever. ${ }^{21}$ These factors in particular serve to identify transfers of bank assets as a discrete institution, and to set them apart as a peculiar subject for discussion. ${ }^{22}$

The social benefits involved in this technique for rescuing one bank by another are imposing. By providing depositors with uninterrupted banking facilities, it may be possible to avert the far-reaching and disastrous consequences of a loss of confidence in the general banking structure of the community. Rescue of one institution in distress, furthermore, may spare other banks in the vicinity the loss of vital cash balances tied up in a closed bank. ${ }^{23}$ As another advantage, the assets of the old bank are administered in an orderly and normal manner by a more or less experienced banking organization. No special procedure, encumbered with exhausting legal technicalities, is necessary, and the transfer can be completed overnight. ${ }^{24}$ This method avoids the waste of a speedy conversion of assets into $\operatorname{cash}^{25}$ and the delay

\& BANKING (1936) $\$ 5722$. For discussion of the privilege of corporations in general to prefer creditors, see Note (1922) 19 A. L. R. 320.

18. Leyvraz v. Johnson, 114 Fla. 396, 154 So. 159 (1934); Luikhart v. Funt, 124 Neb. 642, 247 N. W. 790 (1933); Baird v. First National Bank of Williston, 55 N. D. 856, 215 N. W. 810 (1927). But see First National Bank in Ada v. Jackson, 180 Olka. 77, 79, 70 P. (2d) 88,90 (1937).

19. In Claus v. Farmers \& Stockgrowers State Bank, 51 Wyo. 45,63 P. (2d) 781 (1936), the arrangements were given a peculiar twist, with the directors of the old bank: as the immediate purchasers of the insolvent's assets. But the net effect of the transaction was the same.

20. Ozan Lumber Co. v. Davis Sewing Machine Co., 284 Fed. 161 (D. Del. 1922).

21. Chorpenning v. Yellow Cab Co. of Camden, 113 N. J. Eq. 389, 167 Atl. 12 (1933).

22. For discussions of the liability of a corporation for the debts of its predccessor, see Notes (1933) 82 U. of PA. L. Rev. 172; (1938) 32 Il.. L. Rev. 753; (1930) 44 HARv. L. Rev. 260; (1926) 40 A. L. R. 273.

23. To encourage the absorption, therefore, neighbor banks may put up a fund to protect the transferee institution from loss. Bassett v. City Bank \& Trust Co., 116 Conn. 617, 165 At1. 557 (1933). Or they may execute a guaranty against loss to the new bank. Trust Co. of New Jersey v. Jefferson Trust Co., 186 Atl. 732 (N. J. Sup. Ct. 1936). The validity of these undertakings is discussed in Note (1937) 17 B. U. L. REv. 695; (1937) 2 U. Newark L. Rev. 182.

24. This was literally the case in Security State Bank v. First National Bank, 26 F. (2d) 237 (C. C. A. 8th, 1928).

25. Rapid liquidation consists of a sacrifice of illiquid assets on a market already depressed by the bank failure. A judicial liquidation is ordinarily of this character. A 
of a slower and more conservative policy. ${ }^{20}$ Federal deposit insurance, it is true, now eliminates many of the evils which informal bank combinations are designed to correct. ${ }^{27}$ But the operations of the FDIC, however beneficial, have by no means rendered obsolete the informal combination practice.93 Advantage to the new bank from the transfer consists in the obviation of a contagious bank failure and in the probability that the transferce will retain in the future most of the old bank's patronage. Esprit de corps among the banking fraternity, coupled with sincere concern for the public interest, may also motivate the management of the transferee. But rescue by combination imposes a serious risk on shareholders and creditors of the absorbing institution. Amalgamation is feasible only in the case of a transferor whose assets offer some promise of eventually covering liabilities. If the true value of the old bank's portfolio falls far short of its obligations, the absorbing bank may not be able to withstand this gratuitous burden of extra debt. Indiscriminate and fatal attempts to salvage hopelessly insolvent institutions, accordingly, have occasionally led to invalidation of these wholesale transfers.:-

But most courts have apparently been more deeply impressed with the beneficial aspects of these transactions ${ }^{30}$ and have strained every doetrinal fiber to uphold them against allegations of invalidity. ${ }^{31}$ Rationales abound.

helter-skelter race for priorities among creditors is an ever-present concomitant, involving expensive litigation which saps the insolvent estate. $C f$. Neely v. Rawlings, 64 F. (2d) 655 (C. C. A. 5th, 1933).

26. Delay may be an extreme hardship to creditors whose entire eanital is ticd up in the failed enterprise. As to them, immediate, although partial, disbursement may be far more valuable than eventual full payment.

27. The Corporation must pay insured deposits "as soon as possible" after the banl: closing. Payment may be effected by means of a transferred demand deposit in another insured bank, or through the organization of a new national bank which assumes the insured deposits. 49 ST.AT. 695 (1935), 12 U. S. C. A. $\$ 264(1,6)$ (1936). See generally, Comment (1936) 36 CoL L. REv. 809, 827.

28. Not all banks are embraced in the guaranty scheme. Ey the end of 1937, 1,035 out of 14,882 banking institutions in the country were not insurcd. A:zival Rerors FDIC (1937) 33. And statistical surveys reveal that by far the greater number of banl: failures occur among small state banks. See Brearen, Aurenca:t Bark Famunes (1935) 46. These constitute most of those still outside the deposit insurance system. Arizual REPORT, FDIC (1937) 84. Furthermore, it is the policy of the FDIC to promote the absorption of struggling banks into other insured institutions before failures occur. A::NUAL REPORT, FDIC (1937) 11.

29. Continental Illinois National Bank \& Trust Co. v. Peoples Trust \& Savings Bank, 366 IIl. 366, 9 N. E. (2d) 53 (1937) ; cf. Board of Commissioners of Lalse County v. Citizens Trust \& Savings Bank, 73 Ind. App. 76, 123 N. E. 130 (1919).

30. It is often stated that the practice of rescue by combination is a matter of sound public policy. Harris v. Briggs, 264 Fed. 726, 731 (C. C. A. 8th, 1920); Garvey v. Bankers Trust Co., 214 Iowa 401, 405, 239 N. W. 518, 519 (1931).

31. Such challenge usually comes from stockholders of the old banl, who would otherwise be liable, under the terms of the contract of transfer, to the transferee when it has suffered a deficit from the transaction. See cases cited infra note 71. Another mode of attack is a direct levy of execution on the transferred assets as still the property of the old bank Burkhalter v. Glenville Bank, 184 G3. 147, 190 S. E. 644 (1937). 
It is generally held, for instance, that the conveyance is not an assignment for the benefit of creditors, and so is unaffected by statutes prohibiting finincial institutions from making such assignments. ${ }^{32}$ Statutes containing, by the court's own admission, mandatory language as to a definite procedure for the liquidation of insolvent banks have nevertheless been construed as merely directory. ${ }^{33}$ Since the transaction does not purport to be a merger, compliance with legislative regulations for legal amalgamation is unnecessary. ${ }^{34}$ The transaction is, further, ultra vires of neither bank. ${ }^{35}$ Nor is the Bulk Sales Act an obstacle, since it applies only to transfers of chattels. ${ }^{36}$ Statutes which forbid insolvent banks to make transfers of assets which result in preferences among creditors are circumvented in one fashion or another. ${ }^{37}$ Lastly, although it is universally ruled that the business of a solvent bank may not be destroyed through the alienation of all its assets without stockholders' consent, ${ }^{38}$ the emergency of impending disaster is said to expand the general atthority of the directors to include this drastic action on their own motion..$^{30}$

Solvent banks have on less frequent occasion made use of similar arrangements to secure the benefits of de jure amalgamation without following the requisite, but burdensome, legislative procedure. True, none of the social benefits attending absorption of an insolvent bank are here in evidence. But these transfers present a significantly different factual picture from combina-

32. O'Malley v. Drovers' State Bank, 181 Minn. 1, 231 N. W. 407 (1930); T'atum State Bank v. Woolworth, 65 S. W. (2d) 284 (Tex. Com. App. 1933). The reason commonly assigned for this ruling is that the new bank is bound to pay demands immediately, and not merely out of the proceeds of a liquidation. But cf. Cory Maun George v. Old, 23 F. (2d) 803 (C. C. A. 4th, 1928).

33. Harris v. Briggs, 264 Fed. 726 (C. C. A. 8th, 1920) ; Valley Bank v. Malcolm, 23 Ariz. 395, 204 Pac. 207 (1922) ; Dolhonde v. Tangipahoa Bank \& Trust Co., 153 So. 71 (La. App. 1934). Contra: Cases cited note 29, supra.

34. City National Bank of Huron v. Fuller, 52 F. (2d) 870 (C. C. A. 8th, 1931).

35. Houston v. Drake, 18 F. Supp. 693 (D. Ariz. 1937) (national banks); Sherard State Bank v. Vernon, 243 Ill. App. 122 (1926) (state banks). Contra: Board of Commissioners of Lake County v. Citizens Trust \& Savings Bank, 73 Ind. App, 76, 123 N. E. 130 (1919).

36. Knass v. Madison \& Kedzie State Bank, 269 Ill. App. 588 (1933).

37. See notes 114, ff., infra, and accompanying text.

38. See note 41 , infra.

39. Oskaloosa Savings Bank v. Mahaska County State Bank, 205 Iowa 1351, 219 N. W. 530 (1928) ; Howard v. Republic Bank \& Trust Co., 76 S. W. (2d) 187 (Tex. Civ. App. 1934). This is equally true where national banks are the participants. City National Bank of Huron v. Fuller, 52 F. (2d) 870 (C. C. A. 8th, 1931).

No danger is involved in allowing the respective bank managements to be the sole judges of the expediency of a conveyance, provided good faith is exercised. If the transferor is insolvent, its stockholders have no equity which can be jeopardized. Nor are creditors likely to be left remediless. See notes 90 and 91 , infra, and accompanying text. But stockholders and creditors of the new bank have much at stake. For their protection, as well as in the public interest, the approval of some qualified officer should be a conclition precedent to a combination. At least one state statute makes such approval mandatory. First National Bank of Woodlawn v. Watkins, 295 Ill. App. 572, 15 N. E. (2d) 611 (1938). 
tions involving an insolvent transferor, ${ }^{20}$ one which does not include the evasion of legislation relative to the administration of assets of moribund enterprises. Further, there are ample safeguards for interested parties other than strict obedience to amalgamation statutes.11 The courts have, accordingly, supported these transactions, even though deroid of affirmative public advantage, on the ground that they are not mergers, but merely conveyances of property. ${ }^{42}$

Although the validity of the transfer is likely to be affirmed, several highly controversial problems arise. Of primary importance is the question raised when a creditor of the old bank, whose obligation is seemingly not assumed by the new bank under the terms of the contract, seeks to hold the transieree responsible on his claim. It frequently happens that outstanding obligations of the assignor bank either are expressly excepted, or are overlooked because they do not appear on the books of the transferor through clerical error, embezzlement or other cause. ${ }^{43}$ And if the assignee bank is to be held on these unassumed obligations aside from, or in spite of, its contract, there remains the further problem of the extent of its liability.

It is generally acknowledged that when a bank or other corporation, as well as an individual, transfers property in good faith and for ample consideration, the purchaser takes free of obligation to creditors of the vendor. ${ }^{44}$ But in the teeth of this formula, a majority of decisions have held that the transferee of all, or substantially all, of a bank's assets is answerable for unassumed debts of its predecessor. ${ }^{45}$ One widely-accepted argument in support of this result where the transferor is insolvent is based on the premise that an insolvent bank cannot grant preferences among its creditors. ${ }^{40}$ Since

40. Of course, the two patterns, in certain instances, nuy merge into each other. Thus, the purposes behind a combination may be both to reduce competition and to prevent a failure. Or the solvency of the old bank may be in dispute.

41. Stockholders of the old bank are protected by the rule that the transfer is invalid unless it has their authorization. See Note (1920) 5 A. L. R. 930, 931. Protection of the interests of minority, or dissenting, stockholders in this situation is discussed in Totes (1932) 19 VA. L. REv. 166; (1932) 20 CALIF. L. REv. 420; (1932) 79 A. L. R. 624. If the purpose of the combination is to divert funds from the payment of debts, no reason exists why it may not be annulled as a fraudulent conveyance by an aggrieved creditor.

42. Drovers \& Mechanics National Bank v. First National Bank, 260 Fed. 9 (C. C. A. 4th, 1919) ; Cory Mann George Corp. v. Old, 23 F. (2d) $\$ 03$ (C. C. A. 4th, 1923).

43. It is common to itemize the liabilities that the new bank agrees to adopt. Even a provision that "all liabilities" are taken over is ordinarily qualified by the phrase "as shown by the books" of the transferor. The obligation in question, further, may be a cause of action not reflected on the old bank's books.

44. Alexander v. State Savings Bank \& Trust Co., 281 IIl. App. \&S (1935); Ezzard v. State National Bank, 57 Okla. 371, 157 Pac. 127 (1916). Any ather principle, of course, would make ordinary commercial activity impossible.

45. For instances, see cases cited infra notes $\mathbf{4 7}$ to $\mathbf{5 5}$.

46. This initial principle of equality of treatment may be based on a legislative prohibition of preferences by insolvent banks. Modoc County Bank v. Ringling, 7 F. (2d) 535 (C. C. A. 9th, 1925). Or, in absence of statute, it may stem from the corporation 
partial assumption of obligations by the new bank would give rise to discrimination, thereby voiding the conveyance, the parties are presumed, irrespective of any express agreement, to have intended a legal transaction, i.c., to assume all the transferring bank's obligations. ${ }^{47}$ Similarly, courts have read into the assumption clauses of the instrument of transfer an explicit assumption of all liabilities, ${ }^{48}$ even though the result may be an equally patent misconstruction of the actual intent of the parties.

Another line of reasoning upholding the validity of these transfers is based on the doctrine that the assets of any corporation, particularly when insolvent, constitute a trust fund for the benefit of creditors, who are entitled to share ratably therein. When corporate property is transferred, it remains impressed with this burden unless full value is given in exchange. But the assumption of liabilities is not the complete equivalent of cash payment, and is, accordingly, deemed insufficient consideration to discharge the trust. ${ }^{40}$ The issue of notice is irrelevant; the transaction not being in the ordinary course of business, constructive knowledge is imputed to the purchaser both of the trust character of the property and of all claims upon it..$^{60}$ All creditors of the old bank are thus deemed to have an equitable lien on the assets transferred, which may be enforced while the property is in the hands of the new bank..$^{51}$ The corporation trust fund fiction may also appear in somewhat varied form.52 A less frequently used rationale, but one which is also applicable where the old bank was solvent, brands the transaction "constructively fraudulent" as to a creditor who is left remediless when the old bank is stripped of assets. As a result, the new bank is held in an action in the nature

trust fund theory. Rice v. City of Columbia, 143 S. C. 516,141 S. E. 705 (1928). Or from general considerations of public or legislative policy. See cases cited supra note 18.

47. Caldwell State Bank v. First National Bank, 49 Idaho 110, 286 Pac. 360 (1930). This implicit undertaking has been discovered despite the express understanding of the parties that none but stipulated liabilities are to be adopted. Security State Bank v. First National Bank, 26 F. (2d) 237 (C. C. A. 8th, 1928) (contract judicially approved).

48. Giganti v. Central Republic Bank \& Trust Co., 288 Ill. App. 30\&, 6 N. E. (2d) 486 (1937) ; Sudakovich v. Central Bank of Bingham, 62 Utah 24, 218 Pac. 113 (1923).

49. Erhard v. Boone State Bank, 65 F. (2d) 48 (C. C. A. 8th, 1933). The assump= tion of liabilities is equivalent to cash only on the theory that adequate provision is made for all creditors of the transferee. German-American State Bank v. Farmers \& Merchants Savings Bank, 203 Iowa 276, 211 N. W. 386 (1926). But cf. Claus v. Farmers \& Stockgrowers State Bank, 51 Wyo. 45, 63 P. (2d) 781 (1936) (transferce for cach consideration still subject to burdens).

50. Bates v. Madison County Savings Bank, 222 Iowa 370, 269 N. W. 341 (1936).

51. German-American State Bank v. Farmers \& Merchants Savings Bank, 203 Iowa 276,211 N. W. 386 (1926) (specific exception of certain liabilities deemed irrelevant).

52. Where liabilities assumed fall short of assets transferred, the new bank is answerable on general equitable considerations. Security National Bank of Tulsa v. Cain, 126 Okla. 202, 259 Pac. 572 (1927). The new bank may be responsible in quasi-contract, implying that a depositor has an equitable claim to a portion of the bank's funds. Hug. gins v. Commercial \& Savings Bank, 141 S. C. 480, 140 S. E. 177 (1927). 
of a creditor's bill. ${ }^{53}$ This concept of constructive fraud may also be used to bolster a decision resting primarily on some other ground. Thus, to preserve the transfer from the taint of bad faith, the court may discern an implied engagement to provide for all of the old bank's debts. ${ }^{55}$

The most common basis for the imposition of liability is to characterize the transaction, whether or not the transferor was a going concern, as a de facto merger or consolidation. An enterprise resulting from a merger or consolidation is subject to all the responsibilities of its constituents. ${ }^{\text {ES }}$ A1though ordinarily legal amalgamation requires definite formal action, ${ }^{\text {tr }}$ it is cogently argued that a banking organization which occupies the place of its predecessor for all practical purposes will be deemed to do so for legal purposes as well, ${ }^{58}$ and any delimitation by the parties of obligations to be assumed is ineffectual.59 Courts indulge in this reasoning even though usually the old bank retained its independent corporate existence, ${ }^{\mathrm{CO}}$ and, in some cases, was to participate in an accounting at a future date. ${ }^{01}$ By terming the disposal of all assets a "de facto dissolution," 62 a court may satisfy the principle that an amalgamation necessarily involves the extinction of one or both participating corporations. Even an express stipulation by the parties that there is to be no merger and that the old bank is to remain in existence may be of no avail, as the court professes to look to the substance of the

53. Williams v. Commercial National Bank of Portland, 49 Ore. 492, 90 Pac. 1012 (1907).

54. There may be actual bad faith in a few instances. Collinsville National Banls $v$. Esau, 74 Okla. 45, $176 \mathrm{Pac} 514$ (1918). But in the greater number there has been no suggestion of such secret trust for the transferor or inadequacy of consideration as is ordinarily necessary to render a conveyance fraudulent. The general rule appears to to that the assumption of a debtor's liabilities is sufficient consideration to support, fro tanto, a transfer of his property. Mix v. Yoakum, 138 Cal. App. 290, 31 P. (2d) 1071 (1934).

55. Security State Bank v. First National Bank, 26 F. (2d) 237 (C. C. A. 8th, 1928). See notes 46 and 47 , supra, and accompanying text.

56. See Comment (1935) 45 YALE L. J. 105, 122.

57. Houston v. Drake, 18 F. Supp. 693 (D. Ariz. 1937).

58. Riegel v. Planters' State Bank, 100 Okla. 42, 227 Pac. 105 (1924). Similar considerations surround the argument that the new bank is a successor to the old, the "mere continuation of the same corporate personality." Collinsville National Banl: r. Esau, 74 Okla. 45, 176 Pac. 514 (1918).

59. Mobley v. Hagedorn Construction Co., 16S Ga. 385, 147 S. E. 890 (1929); Yantis v. Osborn, 102 Ind. App. 249, 197 N. E. 686 (1935).

60. First National Bank in Carmen v. Willis, 128 Kan. 681, 280 Pac. 782 (1929). On the other hand, only minor technical elements may be lacling from a iull-fledged statutory assimilation. Commonwealth v. Mierchants National Bank of Allentown, 323 Pa. 145, 185 Atl. 823 (1936), (1937) 3 U. Prtrs. L. Rev. 125.

61. See cases cited supra note 59.

62. See Exchange Bank of Novinger v. Turner, 321 Alo. 1107, 1120, 14 S. W. (2d) 425,430 (1929). 
transaction..$^{63}$ Nor is it necessary, to reach this result, that the new bank have the same stockholders or the same officers, the usual indicia of corporate succession. ${ }^{64}$

The extent of the liability which it is felt the new bank should be required to bear is probably the prime factor in determining which of these several theories will be employed as the foundation for the successor bank's responsibility. ${ }^{65}$ Recovery may be allowed for the full amount of the old bank's obligation, regardless of whether the assets received are sufficient to meet these obligations. This measure of liability logically accompanies the views that the transferee has expressly or implicitly agreed to assume its transferor's entire obligation, ${ }^{66}$ or that the transaction is, in legal contemplation, a merger. ${ }^{67}$ The other alternative is to limit the new bank's extra-contractual liability to the value of resources conveyed. Under this standard of recovery, implied by trust fund doctrine, "outcast" creditors are entitled only to their pro rata portion of the assets transferred. ${ }^{68}$ But even here, the new bank may be required to disburse a greater amount than it has received. For as a practical matter there is apparently no scaling down of the liabilities expressly undertaken by the transferee. ${ }^{69}$ On the other hand, in determining whether the new bank itself ultimately sustains the added burden of "outcast" obligations, it is necessary to consider the possibility that in the event of

63. Mobley v. Hagedorn Construction Co., 168 Ga. 385, 147 S. E. 890 (1929) ; cf. American Railway Express Co. v. Downing, 132 Va. 139, 111 S. E. 265 (1922) (involving commercial corporations).

64. Riegel v. Planters' State Bank, 100 Okla. 42, 227 Pac. 105 (1924); Island City Savings Bank v. Sachtleben, 67 Tex. 420, 3 S. W. 733 (1887) (transferce newly creited).

65. Cf. dissent in Huggins v. Commercial \& Savings Bank, 141 S. C. 480, 513, 140 S. E. 177,188 (1927).

66. Even though the assets received were significantly less than the old bank's liabilities, the new bank may be rigorously held to its contractual obligations. American Bank \& Trust Co. v. Hon, 48 F. (2d) 588 (C. C. A. 7th, 1931) ; Giganti v. Central Republic Bank \& Trust Co., 288 Ill. App. 308, 6 N. E. (2d) 486 (1937).

67. Wilson v. Continental National Bank, 130 Neb. 614, 266 N. W. 68 (1936); cf. Northwest Perfection Tire Co. v. Perfection Tire Corp., 125 Wash. 84, 215 Pac. 360 (1923) (commercial corporations). Some courts, however, while employing the fiction of de facto merger, have regarded it as unfair to extend the transferee's liability beyond the value of property received. Okmulgee Window Glass Co. v. Frink, 260 Fed. 159 (C. C. A. 8th, 1919).

68. German-American State Bank v. Farmers \& Merchants Savings Bank, 203 Iowa 276, 211 N. W. 386 (1926). In some jurisdictions, the trust fund doctrine has been emasculated into the equivalent of a rule against fraudulent conveyances. See note 83 infra. A creditor, accordingly, can recover only an excess of assets received by the transferce. Malcolm v. Valley Bank, 31 Ariz. 60, 250 Pac. 363 (1926), rehearing denied, 31 Ariz. 284, 252 Pac. 190 (1927).

69. The contention that, by virtue of the unanticipated additional liability, there has been a partial failure of consideration for the transferee's express promise to pay cach of the other accounts of the old bank was denied in American Bank \& Trust Co. v. Hon, 48 F. (2d) 588 (C. C. A. 7th, 1931). But cf. Wilson v. Continental National Bank, 130 Neb. 614, 266 N. W. 68 (1936). In any event, the expense of computitis the appropriate deduction from each of the other accounts would be prohibitive. 
loss from the transaction the new bank may be able to enforce the superadded liability of the old bank's stockholders. ${ }^{\text {To }}$ Since only a creditor of a bank can enforce the statutory liability of its stockholder, this question hinges on whether the assignment is construed as an outright sale, or as a pledge of assets, $^{71}$ an issue which plays little or no part in the decisions relative to the new bank's responsibility for its predecessor's debts. Although the tendency in recent adjudications seems to be to allow such reimbursement, ${ }^{72}$ no instance has been discovered in which both questions have bren litigated with respect to the same transaction.

Two further problems illustrate the logical ramifications of the several theories of liability. When the new bank is in liquidation, the merger theory leads to the result that a claim which would have had a priority in a winding up of the old bank may be accorded the same treatment, on the ground that the successor bank has stepped into the shoes of its forerunner in all respects. ${ }^{73}$ If serious attention is paid to the fiction that the entire assets of an insolvent transferring bank are a trust fund, even a general creditor of the old bank may be granted a priority in the new bank's receivership. ${ }^{74}$ Where liability is grounded on an implied assumption, presumably the transferor's general creditors have the same status with respect to the transferee. ${ }^{\text {is }}$ The second problem is presented when the new bank has bound itself to pay only a limited percentage of deposit and other liabilities, and the aggrieved creditor is a depositor who has not assented to the "reorganization" plan or whose account has been overlooked. If the transaction is deemed the equivalent of a merger, the new bank would be responsible for the full amount of the "outcast" claim, because there has been no consensual or other legal diminution in the old bank's liability. One old decision goes to this extreme, ${ }^{70}$ but more recent holdings treat the obligation as if it has been actually or impliedly included in an agreement between two separate institutions.77

Despite the superabundance of available arguments in favor of holding the new bank liable, at least to some extent, for the unassumed debts of the

70. See Notes (1938) 24 VA. L. Rev. 76; (1936) 100 A. L. R. 1276.

71. Compare Hightower v. American National Bank of Macon, 263 U. S. 351 (1923) with Assets Realization Co. v. Howard, 211 N. Y. 430, 105 N. E. 680 (1914).

72. See Note (1936) 100 A. L. R. 1276.

73. Mobley v. Hagedorn Construction Co., $168 \mathrm{G3} .385,147$ S. E. $\$ 90$ (1929). The same conclusion may be reached whenever the creditor was a special depositor in the old bank, the theory being that the creditor has equitable title to a specific res which has passed to the new bank. Bates v. Madison County Sarings Bank, 222 Iowa 370, 269 N. W. 341 (1936).

74. Ex parte Savings Bank of Rock Hill, 73 S. C. 393, 53 S. E. 614 (1906).

75. Cf. Delaney v. Farmers State Bank in Merkel, 115 S. WV. (2d) 736 (Tex. Cir. App. 1938).

76. Island City Savings Bank v. Sachtleben, 67 Tex. 420, 3 S. W. 733 (1897).

77. Sudakovich v. Central Bank of Bingham, 62 Utah 24, 218 Pac. 113 (1923); Waukesha National Bank v. Cooper \& Utter Lumber Co., 213 W'isc. 528, 252 N. W. 150 (1934). No question of involuntary discharge of debt is here involved, since the plaintiff retains all his rights against the debtor, the old bank. 
old bank, a substantial minority of courts have granted the new bank complete immunity in this respect. ${ }^{78}$ An equally varied and, often contradictory, set of justifications has been formulated. The common law rule that an insolvent debtor may, in good faith, prefer certain of his creditors is sometimes said to include banks as well as other corporations. ${ }^{70}$ Under this view a creditor who has been neglected or discriminated against under the terms of the transfer has no cause for complaint. A recent case arrives at this result $^{80}$ even in the face of two relevant statutes apparently prohibiting such discrimination. $^{81}$ A second method of effecting the immunity of the new bank limits anti-preference doctrines to insolvent banks and then points out that the old bank, though perhaps hard pressed, had not passed the verge of insolvency at the time of the transfer. ${ }^{82}$ Preferences may be condoned, furthermore, by arguing that the trust principle does not require that all creditor-beneficiaries share pro rata in a distribution, but merely that as a class they have a priority in liquidation. ${ }^{83}$ Again, the assumption of only a limited number of liabilities may be deemed sufficiently valuable consideration to permit the transferee to take free of other claims. ${ }^{84}$ And even though some creditors are left empty-handed, no basis is discerned for an allegation of fraud. ${ }^{85}$ Claims of de facto merger are countered, even where the officers or stockholders of both banks are largely the same, ${ }^{86}$ by pointing to the continued de jure existence of the old bank, although it may have ceased

78. See cases cited infra note 92 .

79. Neely v. Rawlings, 64 F. (2d) 655 (C. C. A. 5th, 1933) ; Cosmopolitan 'Trust Co. v. S. L. Agoos Tanning Co., 245 Mass. 69, 139 N. E. 806 (1923). Sce Note (1933) 28 ILL. L. REv. 103.

80. Mercantile Home Bank \& Trust Co. v. United States, 96 F. (2d) 655 (C. C. A. 8th, 1938), cert. denied 59 Supp. Ct. 71 (1938). The litigated claim was for federal titxes unpaid by the old bank. While the Federal Government has a statutory lien on the property of a delinquent taxpayer, 45 STAт. 875 (1928), 26 U. S. C. A. 81560 (1935), it is not valid against any purchaser until notice of it has been filed in the required manner. 45 Stat. 875 (1928), 26 U. S. C. A. \& 1562 (1935).

81. Mo. Stat. Anv. (1933) $\$ 5379$ provides that a transfer of a bank's business shall in no wise impair any creditor's position. Although the dissenting judge based his opinion [Mercantile Home Bank \& Trust Co. v. United States, 96 F. (2d) 655, 662 (C. C. A. 8th, 1938)] on this stipulation, the majority opinion dismisses it in a sentence. Id. at 662. Neither opinion makes note of Mo. Star. ANs. (1933) §5318, which provides all preferential transfers by an insolvent bank shall be void.

82. See cases cited note 102 , infra.

83. That is, ail debts must be completely satisfied before funds can be appropriated to any other purpose. Malcolm v. Valley Bank, 31 Ariz. 60, 250 Pac. 363 (1926), rehearing denied, 31 Ariz. 284, 252 Pac. 190 (1927) ; see Knass v. Madison \& Kedzic State Bank, 269 Ill. App. 588, 609 (1933).

84. Peoples National Bank of Rocky Mount v. Morris, 152 Va. 814, 148 S. E. 828 (1929).

85. Drovers \& Mechanics National Bank v. First National Bank, 260 Fed. 9 (C. C. A. 4th, 1919).

86. First State Bank of Mangum v. Lock, 113 Okla. 30, 237 Pac. 607 (1925). 
to do business. ${ }^{87}$ Finally, the new bank may be regarded as merely a liquidating and disbursing agent, responsible to third parties only for what it has affirmatively engaged to do. ${ }^{88}$

In attempting to account for this conflict of decisions, doctrinal considerations seem to be of little real weight, aside from the question of extent of liability. On different occasions, the same court may apply opposing arguments to substantially the same set of circumstances. ${ }^{80}$ Yet an attempt to attach controlling significance to any of the factual elements entering the transaction likewise meets with imperfect success. The one factor of dominant importance appears to be whether or not all the worthwhile assets of the old bank have been transferred beyond the reach of its creditors. In the great majority of instances in which the old bank has been left with nothing out of which it can meet its residual indebtedness, courts have shown extreme unwillingness to leave creditors with the sole remedy of going through the tedious and often futile process of persuing the stockholders and directors of the institution. ${ }^{90}$ It is unnecessary, in this connection, that literally all assets be conveyed away; the same result is reached if "all valuable assets" or "practically all assets" are turned over to the new bank.01 But a respectable minority of cases in this factual category stand squarely outside of the rule, ,2 although several which purport to do so may be explained on other grounds. ${ }^{83}$

87. Carswell v. National Exchange Bank, 165 Ga. 351, 140 S. E. 755 (1927) ; First National Bank in Ada v. Jackson, 180 Okla. 77, 70 P. (2d) Es (1937).

S8. Knass v. Madison \& Kedzie State Bank, 269 Ill. App. 5S8 (1933); Claus v. Farmers \& Stockgrowers State Bank, 51 Wyo. 45, 63 P. (2d) 781 (1936). But of. Miles v. Macon County Bank, 187 M10. App. 230, 173 S. W. 713 (1915) (court unearths implied obligation).

89. Compare, e.g., Garvey v. Bankers Trust Co., 214 Iowa 401, 239 N. IV. 518 (1931) with German-American State Bank v. Farmers \& Mferchants Savings Bank, 203 Iowa 276, 211 N. W. 386 (1926); Wilson v. Continental National Bank, 130 Xeb. 614, 265 N. W. 68 (1936) with Austin v. Tecumseh National Bank, 49 Neb. 412, 69 N. WV. 623 (1896).

90. Erhard v. Boone State Bank, 65 F. (2d) 48 (C. C. A. 8th, 1933); cf. American Railway Express Co. v. Commonwealth, 190 Ky. 636, 228 S. W. 433 (1921), crror dismissed, 263 U. S. 674 (1923).

91. Daniel Banker College v. Abney, 74 F. (2d) 443 (C. C. A. 5th, 1934); Wautesha National Bank v. Cooper \& Utter Lumber Co., 213 Wisc. 528,252 X. W. 150 (1934).

92. Neely v. Rawlings, 64 F. (2d) 655 (C. C. A. 5th, 1933); Mialcolm v. Valley Bank, 31 Ariz. 60, 250 Pac. 363 (1926), rehearing denicd, 31 Ariz. 284, 252 Pac 190 (1927); Knass v. Mladison \& Kedzie State Bank, 269 Ill. App. 5SS (1933); Garvey v. Bankers Trust Co., 214 Iowa 401, 239 N. W. 518 (1931); Austin v. Tecumseh National Bank, 49 Neb. 412,68 N. W. 628 (1896).

93. Creditor's claim would have been unenforceable against old bank: Farmers $\mathrm{Na}$ tional Bank v. Sansing, 285 S. W. 862 (Tex. Civ. App. 1926); People's National Banl: of Rocky Mount v. Morris, 152 Va. 814, 148 S. E. S23 (1929). Aggrieved creditor guilty of laches: Short v. First National Bank, 210 Iown 1202, 232 N. IV. 507 (1930), citcd infra note 95; O'Malley v. Drovers' State Bank of South St. Paul, 181 Mrinn. 1, 231 N. W. 407 (1930). Creditor brought action on theory that transfer was void and sought directly to attach transferred property as still belonging to old bank: Burlshiter v. Glennville Bank, 184 Ga. 147, 190 S. E. 644 (1937); People ex rel. Nelson v. Sherard 
On the other hand, where the old bank has retained enough property to make a remedy against it effective, courts have uniformly denied claims against the new bank. ${ }^{94}$ These results might be taken as illustrative of the proposition that a preference can be created only when all assets are transferred. On the contrary, however, in the event of partial transfer, a material advantage may well be afforded to creditors whose obligations are assumed. Perhaps a more accurate explanation of these cases would be that the courts require a creditor to show that he has no real remedy against the old bank before he can successfully proceed against the new. Only on some such basis is it possible to account for the anomalous and somewhat startling decision in First National Bank in Ada v. Jackson. ${ }^{95}$ Here the court conceded the transfer of all worthwhile assets might be preferential and so void, but declared that only the liquidating agent of the old bank could sue for the return of the transferred assets. 08 But where it is apparent that action against the old bank will be fruitless, no such prerequisite is necessary for a direct proceeding against the transferee. ${ }^{97}$

Whether the old bank was solvent or insolvent at the time of transfer appears to be in itself of but slight consequence when the cases are viewed en masse. In either event there is apparently just as much likelihood that liability for all of the old bank's debts will be fastened on its transferee. ${ }^{\text {as }}$ Most decisions disregard the issue $; 90$ others expressly state the only significant question to be whether the old bank has been picked clean. ${ }^{100}$ When the courts have explicitly considered solvency as an isste, they have travelled in diverse directions, depending on local rules. Where the doctrine obtains

State Bank, 258 Ill. App. 168 (1930). To have imposed liability on transferce would have imputed ultra vires transaction to it. State v. Huxtable, 178 Ark. $361,12 \mathrm{~S}$. W. (2d) 1 (1929).

94. Alexander v. State Savings Bank \& Trust Co., 281 Ill. App. 88 (1935) ; McCollough v. National Bank of Union City, $127 \mathrm{~Pa}$. Super. 452, 193 Atl. 65 (1937). Cf. Short v. First National Bank, 210 Iowa 1202, 232 N. W. 507 (1930).

95. 180 Okla. 77, 70 P. (2d) 88 (1937); (1938) 51 HARv. L. Rev. 548.

96. If the creditor were to be allowed recovery against the new bank, it was said, the result would be an illegal preference in his favor. First National Bank in Adn v. Jackson, 180 Okla. 77, 80, 70 P. (2d) 88, 91 (1937). But no reason was assigncd for not allowing him a pro rata share of the transferred assets, as was done elsewhere when the conveyance was adjudged void. First National Bank of Littlefield v. Neel, $10 \mathrm{~S}$. W. (2d) 408 (Tex. Civ. App. 1928).

97. A creditor's claim, generally, need be neither liquidated nor reduced to judg" ment before it can be enforced against the new bank. See note 109, infra.

98. In 32 out of 52 discovered cases, involving the question of extra-contractual liability, and an insolvent transferor, recovery from the receiving bank was allowed in 21 instances, and denied in 11 . In 20 situations where insolvency was not a factor, recovery was granted 13 times.

99. O'Malley v. Drovers' State Bank of South St. Paul, 181 Minn. 1, 231 N. W. 407 (1930); U. S. Fidelity \& Guaranty Co. v. Citizens National Bank, 13 F. (2d) 213 (D. N. M. 1924).

100. Security State Bank v. First National Bank, 26 F. (2d) 237 (C. C. A. 8th, 1928); Erhard v. Boone State Bank, 65 F. (2d) 48 (C. C. A. 8th, 1933). 
that an insolvent bank may prefer creditors, a new bank which receives all of the transferor's assets would be liable for unassumed debts only if the assignor bank were solvent. ${ }^{101}$ Since in that case the assets conveyed would exceed liabilities assumed, the purchasing bank would be liable as a fraudulent transferee. Where the rule against preferences by insolvent institutions prevails, the new bank is held for all obligations only when a discriminatory transfer has been made by an insolvent institution. ${ }^{102}$ It is difficult, however, to appreciate the reasoning behind these cases. It would seem that here also if the transferring bank were solvent, the transaction would be similarly voidable as fraudulent, providing, as is the case, that the transfer embraces all assets. As indicated above, the question of whether the transaction is nominally one of sale, pledge or bailment for liquidation plays a minor role. All but a few opinions do not trouble to analyze the instruments drawn up by the parties with their complicated provisions for application of the proceeds and for future adjustment of accounts, but rest content with describing the transaction as a "sale" or "transfer" and derote no further attention to the matter. ${ }^{103}$ Nor is actual knowledge on the part of the new bank of the existence of unassumed obligations material. In a typical situation, the officers of neither organization are aware of the liability. ${ }^{104}$ And although officers of the transferee may know of the claim, liability does not always follow. ${ }^{105}$ This fact, however, may be treated as an additional circumstance to warrant judgment against the successor bank. 100

No distinctions may be drawn on the basis of the nature of the unassumed claim. Every species of obligation that has come before a court, except that on an executory contract for personal service, ${ }^{107}$ has been held, other factors aside, to carry over onto the new bank. ${ }^{108}$ Nor does it appear to be necessary

101. See Knass v. Madison \& Kedzie State Bank, 269 Ill. App. 588 (1933). Solveney; is here used in its "bankruptcy" sense: assets at their fair value insufficient to cover liabilities.

102. Short v. First National Bank, 210 Iowa 1202, 232 N. W. 507 (1930); Garvey v. Bankers Trust Co., 214 Iowa 401, 239 N. W. 518 (1931). But if. Erhard v. Boone State Bank, 65 F. (2d) 48 (C. C. A. 8th, 1933).

103. One decision found significance in the fact that the assignment vas formally intended as collateral security only. Overstreet v: Citizens Bank, 12 Okila. 383, 72 Pae. 379 (1903). But it has since been overruled. Collinsville National Bank v. Esau, 74 Okla. 45, 176 Pac. 514 (1918). And other courts have disregarded provisions in the agreement contemplating a reconveyance of unneeded assets. See cases cited suppra note 59.

104. Kentucky Joint Stock Land Bank v. Farmers Exchange Bank, 274 Ky. 525, 119 S. W. (2d) 873 (1938); MIann v. Bank of Greenfield, 323 دfo. 1000, 20 S. WV. (2d) 502 (1929).

105. Carswell v. National Exchange Bank, 165 Ga. 351, 140 S. E. 755 (1927); Knass v. Madison and Kedzie State Bank, 269 Ill. App. $58 S$ (1933).

106. Mobley v. Hagedorn Construction Co., 168 Ga. 385, 147 S. E. $\$ 90$ (1929).

107. Dolhonde v. Tangipahoa Bank \& Trust Co., 153 So. 71 (La. App. 1934).

108. Barber v. First State Bank of Hereford, 37 S. W. (2d) 80 (Tes. Civ. App. 1931) (liability as escrow agent); Commonwealth v. Merchants National Bank of Allen- 
that the claim, although unliquidated, has been reduced to judgment against the old bank before suit is instituted against its transferee. ${ }^{109}$ Moreover, proceedings against the old bank after the transfer may serve to work an estoppel against a claim of merger in a subsequent action against the new bank. ${ }^{110}$

The existence of an apparently applicable federal ${ }^{111}$ or state ${ }^{112}$ statute forbidding preferential treatment of creditors seems to make no appreciable difference, beyond influencing the court in a few cases forcibly to construte the instrument of transfer so as to eliminate the preference. ${ }^{113}$ The statute may be ignored entirely, ${ }^{114}$ or declared inapplicable to the instant situation. ${ }^{\mathbf{1 1 5}}$ Only actual psychological intent to prefer may be regarded as falling within the legislative ban, and it has been frankly announced that a minor discrimination will not be allowed to avoid the whole beneficial transaction.110

town, $323 \mathrm{~Pa} .145$, 185 Atl. 823 (1936) (liability as surety on a bond); Goodbar v. Union \& Planters Bank and Trust Co., 67 S. W. (2d) 562 (Tenn. App. 1933) (liability for breach of trust); Sudakovich v. Central Bank of Bingham, 62 Utah 24, 218 Pac. 113 (1923) (embezzled deposit); Peet v. People's Trust \& Savings Banls, 90 Calif. App. 436, 266 Pac. 300 (1928) (claim for conversion); Dupoyster v. First National Bank of Wickliffe, 29 Ky. L. Rep. 1153, 96 S. W. 830 (1906) (liability to a stockholder). But cf. LaRue v. Bank of Columbus, $165 \mathrm{Ky} .669,178 \mathrm{~S}$. W. 1033 (1915).

109. Delaney v. Farmers State Bank in Merkel, 115 S. W. (2d) 736 (Tex. Civ. App. 1938); cf. Wilson v. Continental National Bank, 130 Neb. 614, 266 N. W. 68 (1936). Accord: Cobb v. Interstate Mortgage Corp., 20 F. (2d) 786 (C. C. A. 4th, 1927).

One decision, in order to avoid the operation of the statute of limitations, enunciates an opposite rule. Williams v. Commercial National Bank of Portland, 49 Ore. 492, 90 Pac. 1012 (1907), cited supra note 53. But cf. Valley Bank v. Malcolm, 32 Ariz. 395, 204 Pac. 207 (1922).

110. First State Bank of Mangum v. Lock, 113 Okla. 30, 237 Pac. 607 (1925). But cf. Wilson v. Continental National Bank, 130 Neb. 614, 266 N. W. 68 (1936).

111. Rev. Stat. \$ 5242 (1875), 12 U. S. C. A. $\$ 91$ (1936). This statute is, of course, applicable only to national banks.

112. TEx. Rev. Stat. (1935): $\$ 532$ substantially follows the federal statute, cited supra note 111.

113. Modoc County Bank v. Ringling, 7 F. (2d) 535 (C. C. A. 9th, 1925); Miller v. First National Bank of South Bend, 103 Ind. App. 99, 1 N. E. (2d) 671 (1936).

The chain of reasoning adducing this result has been discussed above in the text accompanying notes 46 and 47 , supra.

114. Mercantile Home Bank \& Trust Co. v. United States, 96 F. (2d) 655 (C. C. A. 8th, 1938), cert. denied, 59 Sup. Ct. 71 (1938), cited supra note 80. In McCollough v. National Bank of Union City, 127 Pa. Super. 452, 193 Atl. 65 (1937), a national bank: was the discriminatory transferor, but the opinion does not advert to the federal statute, cited supra note 111.

115. A statute providing for the assumption of all liabilities when a bank sells all its assets is inapplicable when there is a sale of specified assets at a specified price, although the whole of the transferring bank's resources is involved. Neely v. Rawlings, $64 \mathrm{~F}$. (2d) 655 (C. C. A. 5th, 1933). An anti-preference statite does not apply to a transfer in good faith for a present consideration, but only to transfers which are in satisfaction of preexisting debts. Burkhalter v. Glennville Bank, 184 Ga. 147, 190 S. E. 644 (1937).

116. Burkhalter v, Glennville Bank, 184 Ga. 147, 190 S. E. 644 (1937); Claus v. Farmers \& Stockgrowers State Bank, 51 Wyo. 45, 63 P. (2d) 781 (1936). 
Even where the court recognizes a breach of a statutory provision and declares the transfer void, the result may be factually the same as that reached under the trust fund doctrine, ${ }^{117}$ or the court may deny the creditor any effective remedy whatever..$^{118}$

None of the considerations thus far discussed completely reflect the real issues implicit in the controversy between a "frozen-out" creditor, whose claim is usually fully meritorious, and the new bank, which has philanthropically undertaken the burdens of its assignor, frequently suffering considerable loss in the process. In allowing recovery, not only is an innocent organization to be penalized, but the additional burden may seriously jeopardize the interest of depositors of both the old and new banks who have refrained from withdrawing their accounts from the transferee in reliance on the financial soundness of the transaction. Furthermore, large holes may be eaten into the capital which public spirited citizens have contributed to the new venture. These fears have been openly expressed in some of the cases decided in favor of the transferee. 119 In line with the almost unanimous policy of regarding these combinations as valid, other courts have admittedly balked at taking any step which might discourage them. ${ }^{120}$ In cases where the old bank has sacrificed the interests of its other creditors to those of its depositors, a decision upholding the discrimination is in accord with the policy, enunciated by statute in an increasing number of states, of preferring depositors in bank liquidations. ${ }^{121}$

But these considerations may be more theoretical than real. Usually the unassumed claim is so minor that the new bank's position would not be impaired by granting it. The very real possibility exists, moreover, that by virtue of the additional business acquired, the new bank has been more than compensated for the obligations it has expressly undertaken.122 The transferee, also, may be able to indemnify itself if the transaction has been so arranged as to permit it to enforce the statutory liability of the old bank's stockholders. ${ }^{123}$ Most courts, accordingly, appear to have felt that the equities weigh most heavily with the neglected creditor.

117. The transferee, having no right or title to the assets in question, holds them in trust for the old bank's creditors. Jackson v. Chapman, 263 S. W. 958 (Tex. Civ. App. 1924).

118. First National Bank in Ada v. Jackson, 180 Okla. 77, 70 P. (2d) 85 (1937), cited supra note 95 . The implication of the decision is that the creditor's only course is to induce the receiver of the old bank to sue the new bank for repossession of all the transferred property.

119. Mercantile Home Bank \& Trust Co., 96 F. (2d) 655,659 (C. C. A. $8 \mathrm{th}, 1938$ ), cert. denied, 59 Sup. Ct. 71 (1938). Short v. First National Bank, 210 Iowa 1202, 1209, 232 N. W. 507,510 (1930).

120. Garvey v. Bankers Trust Co., 214 Iowa 401, 405, 239 N. W. 518, 519 (1931).

121. See Comment (1932) 41 Yale L. J. 432; Note (1933) 86 A. L. R. 1310.

122. See Bowerman v. First Alerchants' National Bank, 211 Ind. 3H, 350, 7 N. E. (2d) 198, 202 (1937); American State Bank of Detroit v. Aaron, 271 Mich. 147, 156, 260 N. W. 141, 144 (1935).

123. See note 70 , supra. 